\title{
A Causality Analysis of Financial Deepening and Performance of Nigerian Economy (1990-2013)
}

\author{
Andabai, Priye Werigbelegha \\ Department of Finance and Accountancy. Niger Delta University, Bayelsa State, Nigeria \\ MaryAnn, Nwamaka Igbodika. PhD \\ Department of Banking and Finance, Anambra State University, Igbariam Campus, Anambra State, Nigeria
}

\begin{abstract}
The study examines the causal relationship between financial deepening and performance of Nigerian economy using time series data (1990-2013). Secondary data was used and collected from the central bank of Nigeria statistical bulletin and national bureau of statistics. Hypotheses were formulated and tested using a causality econometrics model and the study reveals that the variables do not have unit roots. There is also a longrun equilibrium realationship between financial deepening and performance of Nigerian economy and the result confirms that about $70 \%$ short-run adjustment speed from long-run disequilibrium. The study reveals that there is a causal relationship between financial deepening and performance of Nigerian economy. The coefficient of determination indicates that about $63 \%$ of the variations in performance of Nigerian economy can be explained by changes in financial deepening variables. The study therefore recommends that Government policies should be directed towards manipulating the money supply in such a way that will facilitate economic growth and development. The monetary authority CBN should implement policies that will increase the flow of funds and improves the capacity of banks to extend credit to the economy. Security and Exchange Commission should be diligent in the supervision of the operators in the capital market to ensure that efficiency and discipline is restored in the market, so as to increase investors confidence, expand liquidity, mobilize savings and enhances capital accumulation.
\end{abstract}

Keywords: Causality, Analysis, Financial Deepening, Performance, Nigerian, Economy

\section{Introduction}

The search for ways of improving the standard of living of citizens has opened the corridors for alternative view points on paradigms of economic growth and development (Andabai, 2015). Therefore, financial deepening had been identified as one of those strategies whose implementation can quicken the pace of development and the effect of this strategy need to be determined and examined from time to time especially for developing economies like Nigeria. Financial deepening is to improve economic performance through increased competitive efficiency within financial markets thereby indirectly benefiting non-financial sectors of the economy (Chiawa and Abur, 2013). The Nigerian financial system is broadly divided into two sub-sectors, the informal and formal sectors (Onwumere, et al 2012): the informal sector has no formalized institutional framework, no formal structure of rates and it comprises the local money lenders, thrifts, savings and loans associations. However this informal sector is poorly developed and not fully integrated into the formal financial system and its effect on the economy still remain on speculation. The Nigerian banking sector which is the formal sector has remained competitive, and as such fewer large banks control the segment of the market in terms of total assets, total liabilities and total credit in the banking system which fails to induce economic growth.

Financial deepening implies the level of development and innovation of traditional and non-traditional financial services in a free-market economy (Valverde, et al. 2004 in Chiawa and Abur, 2013). While Nzotta and Okereke (2009) ascertain that financial deepening is the ability of financial institutions in an economy to effectively mobilize savings for investment purposes. The financial deepening vigorously attracts the reservoir of savings and idle funds and allocates same to entrepreneurs, businesses, households and government for investments projects and other purposes with a view of returns which forms the basis for economic development. Despite this, Nigerian financial deepening has failed to experience impressive performance such as attraction of foreign investment or halt capital flight. Inspite of various reforms in the Nigerian banking sector, the sector still have not addressed the financial gaps in the system. This is because neither domestic savings nor investments in country have appreciably increased since the introduction of the reforms as the sector still remained largely oligopolistic and uncompetitive, as few large banks control the greater segment of the market in terms of total assets, total liabilities and total credit in the banking system.

It has been the question of whether financial deepening is a mere respond to the growth in the economy or is it financial deepening that spurs economic growth? According to Onwumere, et al (2012), causal relationship between financial deepening \& economic growth can be express in two views namely : a supply leading hypothesis \& demand leading hypothesis. A supply-leading hypothesis states that the presence of efficient financial markets increases the supply of financial services in advance of the demand for them in the 
real sector of the economy. Thus while the demand-leading hypothesis holds that financial deepening does not promote economic growth in Nigeria. It is the contention of this hypothesis that a well-functioning financial institution can promote overall economic efficiency. The two views appear to be in conflict with each other revealing opposing patterns of the relationship between financial deepening and economic growth, each having different implications for policy makers. However, it is the background that this paper seeks to examine the analysis of financial deepening and the performance of Nigerian economy.

\section{Theoretcal Framework}

The theoretical framework of the study predicated on financial deepening theory that refers to the increased provision of financial services by financial intermediaries with a wider choice of services geared to all levels of society. Mackinnon and Shaw (1973) identified two theories that are related to financial deepening they are financial liberalization theory and financial repression theory. According to liberalization theory, in a full liberalized capital account regime, banks and corporations are allowed to borrow freely. They may need to inform the authorities but permission is granted almost automatically, reserve requirement might be in place but are lower than 10 percent. In addition, there are no special exchange rates for either the current account or the capital account transaction; or is there any restriction to capital outflows. Similarly, a fully liberalized financial system is characterized by lack of controls on lending and borrowing interest rates and certainly, by the lack of credit controls, that is, no subsidies to certain sectors or certain credit allocation. Also, deposits in foreign currencies are permitted in a fully liberalized stock market, foreign investors are allowed to hold domestic equity without restrictions and capital, dividend and interest can be repatriated freely within two years of the initial investment. In this scenario, it is expected that there should be various forms of financial instruments in response to the need of the operators in the system (Akinlo and Egbatunde, 2010). On the other hand, financial repression means that government hold financial market under the repression by interfering them.

Nzotta and Okereke, 2009) stated that the relationship between financial development and economic growth can be expressed in three different ways: supply leading hypothesis, demand following hypothesis and bi-directional causality. According to them, supply leading hypothesis supports a positive impact of financial development on economic growth. it then implies that financial development impacts on level of development in every economy. They explained that demand following hypothesis states that finance actually responses to change that happen in the real sector. Put differently, variations in the stock of financial assets would be a function of growth in the real sector of the economy. Bi-directional causality hypothesis, according to them is somewhere between these two in that it claims mutual impact of finance and growth. Kiyotaki and Moore (2005), identified three stages of financial deepening: At first stage or region, the economy is underdeveloped and virtually every transaction is done with cash as there is little or no trust among the players. More so, the supply of private paper is small and agents savings demand can be satisfied only through the use of outside money, green paper, which has zero net return. At the second region, is more financially developed economies, with higher degree of trust. In these economies there is a liquidity premium and investing agents supply inside money, red paper, by bundling part of the output from their projects. At the third stage is the existence of economy with a reasonably abundant, with too little money relative to bonds. In response to the liquidity shortage of the economy makes a remarkable response. Each agent holds an elaborate overlapping savings portfolio as a means of getting round the inconvenience of having to keep the illiquid bond over two nights until they mature.

Dornbusch and Fischer (1978) as cited in Hemachandra (2003) stressed that the ideas and concepts surrounding financial deepening occurs due to an expansion in government expenditure. Keynes (1963) opined that in order to reach full employment, the government should inject money into the economy by increasing government expenditure. It follows that increase in government expenditure increase aggregate demand and income, thereby raising demand for money. Disequilibrium situation is usually the result when this happens and this is resolved by reducing private investments resulting from higher interest rates. Since higher interest rates lower private investment, an increase in government expenditure promotes investments and reduces private investments concurrently. But McKinnon (1973) and Shaw (1973) disagree with this theory and came up with a rival hypothesis that depicts a positive relationship between interest rate and financial deepening. They opined that developing countries have repressed economies with ceiling on interest rates and limitations in credit availability which imposes restrictions on growth (Victor and Omidio, 2007).

\section{Empirical Review}

Onwumere, et al (2012) examined the impact of financial deepening on economic growth in Nigeria for the period 1992 to 2003. The study adopted supply-Leading hypothesis thereby using variables such as broad money velocity, money stock diversification, economic volatility, market capitalization and market liquidity as proxies for financial deepening and gross domestic product growth rates for economic growth. The paper discovered that broad money velocity and market liquidity promote economic growth in Nigeria while money stock diversification, economic volatility and market capitalization do not. Akinlo and Egbetunde (2010) examined the 
long-run and causal relationship between financial development and economic growth for ten countries in subSaharan Africa using the vector error correction model (VECM). The study revealed that financial development is co-integrated with economic growth in the selected ten countries in sub-Saharan African countries. it went in central African Republic, Congo Republic, Gabon, and Nigerian while economic growth Granger causes financial development in Zambia and a bidirectional relationship between financial development and economic growth was found in Kenya, Chad, South Africa, Sierra Leone and Swaziland. Okpara (2010) assessed the relative potency of financial repression and liberalization in Nigeria. The study selected periods that would reflect important policy periods in Nigeria. The study multiple regression analysis to estimate the model constructed for the research. The results of the study reveal that financial development during the period of financial liberalization significantly impact more on the growth variable (GDP).

Most studies review the link between finance and economic growth. For example, Johannes et al. (2011) using Johasen cointegration established positive relationships between financial development and economic growth in the long run and short run for Cameroon for the period 1970-2005 for Cameroon at 5\% level of significance. The result agreed that financial sector development cause economic growth in the long run and the short run. Economic growth is as a result of financial sector development.Azege (2004) examines the empirical relationship between the level of development by financial intermediaties and growth. The study employed data on aggregate deposite money bank credit over time and gross domestic product to establish that a moderate positive relationship exist between financial deepening and economic growth. He concludes that the development of financial intermediary institutions in Nigeria is fundamental for overall economic growth. Wadud (2005) examines the long-run causal relationship between financial development and economic growth for 3 South Asian countries namely India, Pakistan and Bangladesh. The study employed a cointegrated vector autoregressive model to assess the long-run relationship between financial development and economic growth. The results indicate causality between financial development and economic growth.

Odihiambho (2004) investigates the role of financial development on economic growth in South Africa. The study usus three proxies of financial development namely; the ratio of M2 to GDP, the ratio of currency to narrow money and the ratio of bank claims on the private sector GDP against economic growth proxied by real GDP per capita. He employed the Johansen-Juselius cointegration approach and vector error correction model to empirically reveal overwhelming demand-following response between financial development and economic growth. The study totally rejects the supply leading hypothesis.Waqabaca (2004) examines the causal relationship between financial development and growth in Fiji using low frequency data from 1970 to 2000 . The study employed unit root test and cointegration technique within a bivariate VAR framework. Empirical results suggest a positive relationship between financial development and economic growth for Fiji with causality running from economic growth to financial development. He posits that this outcome is common with countries that have less sophisticated financial systems. Unalmis (2002) investigates the direction of causality between financial development and economic growth in Turkey using Granger non-causality in the context of VEC model. The study finds that in the long run. There exists bidirectional causality between financial deepening and economic growth.

Adam (2011) examines how efficient the financial intermediation process has been in Nigeria's growth performance. The study employed the OLS approach. The empirical results show that financial intermediation process is sub-optimal and caused by high lending rate. High inflation rate, low per capita income, and poor branch networking. Hemachandra (2003) investigated the validity of financial deepening paradigms in the context of Sri Lanka and the effects of financial deepening on savings and investment that promotes growth. Results of the study show that there are several factors other than interest rates influencing financial deepening in Sri Lanka. The study also confirms the neo-structuralists hypothesis which claims that financial deepening has reduced provision of credit to the informal sector. Sackey and Nkrumah (2012) examined the effects of financial sector development on economic growth in Ghana using Johansen Co-integration analysis. The study also examined empirically the causal link between financial sector development and economic growth in Ghana. The result of the study shows that, there is a statistically significant positive relationship between the financial sector development and economic growth in Ghana.

\section{Research Methodology}

We adopted the ex-post-facto research design. Secondary data was used and collected from national bureau of statistics and CBN statistical bulletin and the study also considered using annual data because quarterly data may not be accessed for some of the variables. The study proxy financial deepening to broad money supply, market capitalization and credit to the private sector to represent the independent variables and while performance of Nigerian economy was proxy to gross domestic product to represent dependent variable as indicated in appendix I. 


\section{Model Specification}

Model specification involves the determination of the dependent and explanatory variables based on specified theoretical sign and size of the parameters. The study adopted Levine (2005) modified standard growth regression equation in line with the objectives of this paper is to examine the empirical analysis of financial deepening and performance of Nigerian economy as: GDP $=f\left(\mathrm{M}_{2}, \mathrm{CPS}, \mathrm{MAC}\right)$.

Therefore, the re-modified model for this study is stated as:

$\mathrm{GDP}=\mathrm{a}+\mathrm{b}_{1} \mathrm{M}_{2}+\mathrm{b}_{2} \mathrm{MAC}+\mathrm{b}_{3} \mathrm{CPS}+\mathrm{u}$.

Where:

GDP $=$ Gross Domestic Product

$\mathrm{M}_{2}=$ Broad Money Supply

MAC $=$ Market Capitalization

$\mathrm{CPS}=$ Credit to the Private Sector

$\mathrm{a}, \mathrm{b}_{1}, \mathrm{~b}_{2}, \mathrm{~b}_{3}=$ Regression parameters

$\mathrm{U}=$ stochastic error term which absorbs the influence of omitted variables.

\section{Research Hypotheses}

$\mathbf{H}_{\mathbf{0 1}}$ : There is no significant long-run relationship between financial deepening and performance of Nigerian economy.

$\mathbf{H}_{\mathbf{0 2}}$ : There is no causality between financial deepening and performance of Nigerian economy.

\section{Data Presentation andAnalysis}

The tests for stationary of the variables were done using the Augmented Dicker Fuller (ADF) Unit Root Tests. The results in table 1 show that all the variables are integrated at levels i.e. 1(1) at the $5 \%$ or $1 \%$ level of significance.

Table 1: Unit Root Tests Analysis

\begin{tabular}{|l|l|l|l|l|}
\hline \multicolumn{1}{|c|}{ Variables } & \multicolumn{1}{c|}{$\begin{array}{c}\text { ADF test } \\
\text { Statistics }\end{array}$} & $\begin{array}{c}\text { Mackinnon critical } \\
\text { vale @ 5\% }\end{array}$ & $\begin{array}{c}\text { No of the time } \\
\text { difference }\end{array}$ & Remark \\
\hline GDP & 3.3254645 & -2.564879 & $1(0)$ & Stationary \\
$\mathrm{M}_{2}$ & -6.8765974 & -2.645365 & $1(1)$ & Stationary \\
MAC & -5.9796204 & -2.756898 & $1(1)$ & Stationary \\
CPS & 3.3426572 & -2.564784 & $1(1)$ & Stationary \\
\hline
\end{tabular}

Notes: (1) $1 \%$ level of significance, $5 \%$ level of significance, $10 \%$ level of significance.

(2) The tests accepted at 5\% level of significance.

(3) Decision rule -The critical value should be larger than the test statistical value for unit root to exist Source: Researcher's Estimation using- E-views 3.1.

\section{Test for Co-Integration}

Having found that all the variables are stationary at first difference, the next step is to perform Johansen co-integration procedure to ascertain whether gross domestic product (GDP), financial deepening $\left(\mathrm{M}_{2}\right)$, market capitalization (MAC) and credit to the private sector (CPS) are co-integrated in the same order. The results of the test are presented in table 3 and the null hypothesis of no co-integration among the variables (that is, $r=0$ ) is tested against the alternative hypothesis of no co-integration is rejected at the 5 percent significance level. However, the null hypothesis that rd" 1 could not be rejected against the alternative $r=2$, suggesting the presence of a unique co-integrating relationship among variables. Therefore a long-run relationship exists among the variables as indicated by the likelihood ratio that is greater than the critical values both at 1 percent and 5 percent level of significance in table 2 .

Table 2: Multivariate Johansen's Co-integration Test Result.

\begin{tabular}{|l|l|l|l|l|l|l|}
\hline Null hypothes & $\begin{array}{l}\text { Alternative } \\
\text { hypothesis }\end{array}$ & Eigen value & Likelihood ra & $\begin{array}{l}\text { Critical vales } \\
5 \%\end{array}$ & $\begin{array}{l}\text { Critical value } \\
1 \%\end{array}$ & $\begin{array}{l}\text { Hypothesized } \\
\text { No. of CE(s) }\end{array}$ \\
\hline $\mathrm{r}=0$ & $\mathrm{r}=1$ & 0.76571 & 95.98938 & 56.31 & 47.43 & None $^{* *}$ \\
\hline $\mathrm{rd} \leq 1$ & $\mathrm{r}=2$ & 0.71202 & 78.80109 & 45.42 & 32.62 & At most 1 \\
\hline $\mathrm{rd} \leq 2$ & $\mathrm{r}=3$ & 0.65820 & 69.71387 & 25.36 & 27.31 & At most 2 \\
\hline $\mathrm{rd} \leq 3$ & $\mathrm{r}=4$ & 0.34524 & 19.84468 & 11.62 & 14.43 & At most 3 \\
\hline
\end{tabular}

Source: E-views Econometrics 5.0

Note:* $(* *)$ denotes rejection of hypothesis at 5\% (1\%) significance level.

\section{Vector Error Correction Model}

The existence of long-run cointegrating equilibrium provides for short-run fluctuations, in order to straighten out or absolve these fluctuations, an attempt was made to apply the Error Correction model (ECM) Ibenta (2012). 
The Error Correction coefficient contains information about whether the past values affect the current values of the variable under study and the significant coefficient implies that past equilibrium errors play a role in determining the current outcomes and the information obtained from the the ECM is related to the speed of adjustment of the system towards long-run equilibrium and the short-run dynamics are captured through the individual coefficients of the difference terms.

Table 3 : Vector Error Correction Estimates

\begin{tabular}{|c|l|l|l|l|}
\hline Variable & Coefficient & Std. Error & t-Statistic & Prob. \\
\hline ECM $\left._{-1}\right)$ & -0.7009176 & -0.423205 & 0.000771 & -0.010008 \\
\hline $\mathrm{D}\left(\mathrm{GDP}_{-1}\right)$ & 1.7345701 & 6.960191 & 7.029692 & 0.000123 \\
\hline $\mathrm{D}\left(\mathrm{GDP}_{-2}\right)$ & 1.3436699 & -0.641147 & $-5.58 \mathrm{E}-07$ & 0.000245 \\
\hline $\mathrm{M}_{2}$ & 2.7865934 & 0.986368 & -3.179776 & 0.013011 \\
\hline $\mathrm{MAC}$ & 0.4234039 & 0.243352 & 1.262268 & 0.242409 \\
\hline $\mathrm{CPS}$ & 0.5464665 & 0.468375 & 0.635123 & 0.007586 \\
\hline $\mathrm{C}$ & 0.7862898 & -2.201398 & -1.48661 & 0.000780 \\
\hline R - squared & 0.630991 & Mean dependent var & 54.86846 \\
\hline Adjusted R-squared & 0.526238 & S.D. dependent var & 5.023003 \\
\hline S. E. of regression & 3.635216 & Akaike info criterion & 5.646215 \\
\hline Sum squared resid & 105.7184 & Schwarz criterion & & 5.754732 \\
\hline Log likelihood & -28.05418 & R - correlation & & 0.621546 \\
\hline Prob (F-statistic) & 5.546330 & Durbin - Watson stat & 1.772339 \\
\hline
\end{tabular}

Source: Econometrics-View - 7.0

From table 3, the erro-correction coefficient is statistically significant and has a negative sign, which confirms a necessary condition for the variables to be co-integrated. There is also a long-run equilibrium realationship between financial deepening and performance of Nigerian economy and the result confirms that about $70 \%$ short-run adjustment speed from long-run disequilibrium. The study reveals that there is a causal relationship between financial deepening and performance of Nigerian economy. From table 3 also shows that the coefficient of correlation is $\mathrm{R}=0.621546(62 \%)$, this means that the financial deepening and economic performance in Nigeria are related and the relationship is strong and positive. However, the positive relationship here means that an increase in financial deepening will lead to an increase in the performance of Nigrian economy and vice versa. The coefficient of determination indicates that about $63 \%$ of the variations in economic performance in Nigeria can be explained by changes in the financial deepening variables $\left(\mathrm{M}_{2}, \mathrm{CPS}\right.$ and MAC) in the economy. This implies that a good portion of economic performance trends in the Nigerian economy is explained by the financial deepening variables. The F-statistics of 5.54633 which is significant at $5 \%$ confirms the relationship between financial deepening and performance of Nigerian economy and furthermore, the influence of the explanatory variables on the dependent variable is statistically significant and this is also confirmed by the F-probability which is statistically zero and finally, the value of Durbin-Watson (DW) signifies the absence of autocorrelation.

Table 4: Result of Pairwise Granger-Causality Test (1990-2013) with 2-period Lag length

\begin{tabular}{lcccc}
\hline Null Hypothesis: & Obs & F-Statistic & Probability & Decision \\
\hline \hline MAC does not Granger Cause GDP & 22 & 4.86341 & 0.76209 & Causality \\
GDP does not Granger Cause MAC & & 5.97105 & 0.56100 & Causality \\
\hline \hline CPS does not Granger Cause GDP & 22 & 2.97594 & 0.43881 & Causality \\
GDP does not Granger Cause CPS & & 2.87591 & 0.65074 & Causality \\
\hline \hline $\mathrm{M}_{2}$ does not Granger Cause GDP & 22 & 5.57678 & 0.54533 & Causality \\
GDP does not Granger Cause M & & 2.57434 & 0.07362 & Causality \\
\hline \hline CPS does not Granger Cause MAC & 22 & 5.86762 & 0.79876 & Causality \\
MAC does not Granger Cause CPS & & 4.97810 & 0.09852 & Causality \\
\hline \hline $\mathrm{M}_{2}$ does not Granger Cause CPS & 22 & 8.97652 & 0.78174 & Causality \\
$\mathrm{CPS}_{2}$ does not Granger Cause M & & 6.64593 & 0.56943 & Causality \\
\hline \hline $\mathrm{M}_{2}$ does not Granger Cause MAC & 22 & 7.56439 & 0.76634 & Causality \\
MAC does not Granger Cause $\mathrm{M}_{2}$ & & 3.76588 & 0.98088 & Causality \\
\hline \hline
\end{tabular}

Note: The decision rule of a causality test states that if the probability value of the estimate is higher than the $5 \%$ ( 0.05) level of significance, we accept the null hypothesis, and vice versa.

To determine the direction of causality between the variables, the Engle and Granger (1987) causality test was performed on the variables as indicated in table 4. The Granger causality investigated the predictive content of one variable beyond that inherent in the explanatory variables itself. The results of the Granger causality test indicate that economic growth (GDP) has causality with MAC (market capitalization), CPS (credit to the private sector) and $\mathrm{M}_{2}$ (financial deepening ). This implies that there is causality between financial deepening variables and performance of Nigerian economy. 


\section{Discussion of Findings}

The erro-correction coefficient is statistically significant and has a negative sign, which confirms a necessary condition for the variables to be co-integrated. There is also a long-run equilibrium realationship between financial deepening and performance of Nigerian economy and the result confirms that about $70 \%$ short-run adjustment speed from long-run disequilibrium. The study reveals that there is a causal relationship between financial deepening and performance of Nigerian economy. There is a positive significant relationship between financial deepening and economic growth in Nigeria. The relationship is strong because the coefficient of the explanatory variable is statistically above 5\% significant level. And the coefficient of determination is $63 \%$ of variations in GDP that can be explain by changes in financial deepening variables $\left(\mathrm{M}_{2}, \mathrm{CPS}\right.$ and MAC). This implies that a good portion of economic performance trends in the Nigerian economy is explained by the financial deepening variables (broad money supply, credit to the private sector market capitalization). The analysis also shows that there is a strong positive significant relationship between financial deepening and the performance of Nigerian economy, because the coefficient of correlation is $62 \%$ and finally, the value of Durbin-Watson (DW) signifies the absence of autocorrelation.

\section{Conclusion and Recommendations}

Financial deepening in the country patterned to play special role of financial intermediation to ensure that funds get to the investors of the economy sufficiently that will enhance economic growth and development (Okpara, 2010). Therefore, the study recommends that, Government policies should be directed towards manipulating the money supply in such a way that will facilitate economic growth. Regulators like securities and exchange commission should be diligent in the supervision of the market to ensure that efficiency and discipline is restored. CBN, should encourage banks to be efficient in their financial intermediation function by ensuring that ensure that funds from the surplus sector is efficiently channeled to the deficit sector of the economy. Government through its intervention programme should ensure that more credits are made available to the private sector to promote entrepreneurial response in various sector of economy which will in turn spur economic growth. Most importantly, through domestic debt issuance, countries use and recycle their own savings towards their investment needs rather increase their external debt.

\section{Contribution to Knowledge}

The study was able to re-modify the growth model by Levine (2005) and expanded the existing contemporary literatures, empirical review, geographical spreads and updated the data of the study that will enable researchers and scholars to use it for further studies. Consequently, from the results, this study has also contributed to knowledge by discovering that Nigerian economy has a direct causal relationship with financial deepening. The factor responsible for this can be traceable to increased provision of financial services by the financial intermediaries in the economy.

\section{References}

Andabai, Priye.W. \& Bingilar, Paymaster Frank (2015). Deposit Mobilization and Lending Behaviour of Banks in Nigeria (1987-2013). International Journal of Advanced Studies in Business Strategies and Management. 3(1), Pp. 243-255.

Andabai, Priye.W. and Austin, O. Achugbu (2015). The Collapse of Lehman Brothers and Merril Lynch: A Lesson for the Nigerian Banking Industry. African International Multi-Disciplinary Journal. 9(1), Pp. 237-251.

Andabai, Priye. W. (2014). Determinants of Financial Liberalization and Economic Growth in Nigeria (19872013). Being a Paper presented at the 2014 International Conference, Sub-Sahara Africa and Transformation Question, Organized by Faculty of Management Sciences, Nnamdi Azikiwe University Awka-Nigera on October $15^{\text {th }}-18^{\text {th }} 2014$.

Andabai, Priye. W. (2015). An Unpublished Lecture Note on Bank Lending and Loans Administration. Department of Finance and Accountancy, Niger Delta University, Bayelsa State, Nigeria.

Andabai, Priye. W. (2014). An Unpublished Lecture Note on Marketing of Financial Services. Department of Finance and Accountancy, Niger Delta University, Bayelsa State.

Andabai, Priye. W. (2015). An Unpublished Lecture Note on Introduction to Financial Institutions. Department of Finance and Accountancy, Niger Delta University, Bayelsa State, Nigeria.

Akinlo, A.E \& Egbatunde, T. (2010). Financial Development and Economic Growth: The Experience of 10 SubSaharan African Countries Revisited. The Review of Finance and Banking. 2(1), Pp.17- 28.

Ard, O.P \& Damar, H.E. (2006). Financial Sector Deepening and Economic Growth: Evidence from Turkey. Retrieved on 24/1/13. From www.luc.edu/orgs/meea/volume9/pdfs/

Arahan Ozcan \& Yilgor M(2011). Financial Deepening and Economic Growth in Turkey. MIBES Transactions. 5(2), Pp. 19-29. 
Baridam, D.M.(2002).Research Methods in Administrative Science. Port Harcourt University Press.

Torruam, J.T; Chiawa, M.A and Abur, C.C.(2013). Financial Depening and Economic Growth in Nigeria: Application of Cointegration and Causality Analysis. $3^{\text {rd }}$ International Conference on Intelligent Computational Systerm (ICIC'2013). April 29-30, Singapore.

Christopoulos, D.K \& Tsionas, E.G (2004). Financial Development Economic Growth: Evidence from Panel Unit Root and Co-integration Tests. Journal of Development Economics. 77(65), Pp.55-71.

Demetriades, P.\& Rousseau, P.L. (2011). The Changing Face of Financial Development. Retrieved on 24/1/13 from www.gla.ac.uk/../

Fritz, R.G. (2014). Economic Development and Financial Deepening: A Study of Causation and Dynamics. Development. Retrieved on 24/1/13 from www.systemdynamics.org/conferences/1985/

Gerald, V.F. (2006). Financial Development and Economic Growth: A Critical View. Retrieved on 24/1/13 from www.un.org/en/development.

Hasana, L; Koetter, M.; Lensink, R. \& Meester, A.J (2008). Bank Efficiency, Depth, and Economic Growth. Retrieved on 24/1/13 from www.cass.com/city.ac.uk/..

Ibenta, Steve,N.O.(2012). Research Monograph:Guidelines for Seminers Papers, Thesis \&Projects Reports. 2228 Regina Caeli Rd, Awka Anambra State, Nigeria.

Johannes. A T; Njong, A.M. \& Cletus, N. (2011). Financial Development and Economic Growth in Cameroon (1970-2005). Journal of Economics and International Finance. 3(6), Pp. 367-375.

Kiyotaki, N. \& Moore, J. (2005). Financial Deepening. Journal of the European Economic Association. 3(2-3), Pp.701-713.

Kar, S. \& Mandal, K. (2012). Reexamining the Finance-Growth Relationship for a Developing Economy: A Time Series Analysis of Post-Reform in India.IEG Working Paper No. 313, Retrieved on 24/1/13 from.www.iegindia.org/workpap/wp313pdf

Kularatne, C. (2001). An Examination of the Impact of Financial Deepening on Long-Run Economic Growth: An Application of a VECM Structure to a Middle Income Country Context. Retrieved on 24/1/13 from www.tips.org.za/node/1395

Odhiambo, N.M. (2004). Is Ffinancial Development still Spur Economic Growth? A Causal Evidence from South Africa Savings and Development. 2(8), Pp. 47-62.

Okpara, G.C. (2010). Relative Potency of Financial Repression and Liberalization On Financial Development and Economic Growth: An Empirical Survey. American Journal of Scientific and Industrial Research. 1(3), Pp. 643-650.

Onwumere, J.U.J; Ibe, I.G; Ozoh, F.O. \& Mounanu, O. (2012). The Impact of Financial Deepening On Economic Growth: Evidence from Nigeria. Research Journal of Finance and Accounting. 3(10), Pp. 64-71.

Onwumere, J.U.J.(2005). Business and Economic Research Method, Lagos. Don-Vinton Ltd.

Nzotta, S.M. \& Okereke, J.E.(2009). Financial Deepening \& Economic Growth: An Empirical Investigation. Africa Journal \& Accounting Economic, Finance \& Banking Research. 5(5), Pp.52-75.

Nzotta,S.M. (2014). Money, Banking and Finance: Theory and Practice. Revised Edition, Hudson-Jude. Owerri, Nigeria.

Sackey, F.G. \& Nkrumah, E.M. (2012). Financial Sector Deepening and Economic Growth in Ghana. Journal of Economics and Sustainable Development.3(8), Pp. 122-140.

Unalmis, D. (2002). The Causality between Financial Development and Economic Growth. The Case of Turkey. 06100. Ankara.

Vitor, S. \& Emidio, J (2007). Financial Deepening and Economic Growth in Mozanbique. Retrieved on 24/1/13 from http://repositorio-iuo.iscte.pt/handle/10071/674

Vuranok, S. (2009). Financial Development and Economic Growth in Mozambique. Retrieved on 24/1/13 from www.yasin.com/selda+vuranok/check+people

Wadud, M.A (2005). Financial Development and Economic Growth. A Cointegration and ECM Approach for South Asian Countries. Paper Presented at International Conference of the Asian Law and Economics Association at Seoul National University, South Korea on 24-25 June.

Waqabaca, C. (2004). Financial Development and Economic Growth in Fiji Working Paper 2004/03. Economics Department, Reserve Bank of Fiji. 
Appendix 1: Financial Deepening and the Performance of Nigerian Economy (1990-2013)

\begin{tabular}{|c|c|c|c|c|}
\hline YEAR & $\begin{array}{c}\text { Gross Domestic } \\
\text { Product (GDP) } \\
\text { (N'billion) } \\
\end{array}$ & $\begin{array}{c}\text { Credit to the } \\
\text { Private Sector } \\
\text { (CPS) (N'billion) }\end{array}$ & $\begin{array}{c}\text { Market } \\
\text { Capitalization } \\
\text { (MAC) (N'Billion) }\end{array}$ & $\begin{array}{c}\text { Broad Money } \\
\text { Supply }\left(M_{2}\right) \\
\text { (N'billion) } \\
\end{array}$ \\
\hline 1990 & 472.65 & 33.55 & 16.45 & 52.86 \\
\hline 1991 & 545.67 & 41.35 & 23.13 & 75.40 \\
\hline 1992 & 875.34 & 58.12 & 31.24 & 111.11 \\
\hline 1993 & $1,089.68$ & 127.12 & 47.54 & 165.34 \\
\hline 1994 & $1,399.70$ & 143.42 & 66.34 & 230.29 \\
\hline 1995 & $2,907.36$ & 180.00 & 180.43 & 289.09 \\
\hline 1996 & $4,032.30$ & 238.60 & 285.84 & 345.85 \\
\hline 1997 & $4,189.25$ & 316.21 & 281.90 & 413.28 \\
\hline 1998 & $3,989.45$ & 351.96 & 262.63 & 488.15 \\
\hline 1999 & $4,679.21$ & 431.17 & 300.04 & 628.95 \\
\hline 2000 & $6,713.57$ & 530.37 & 472.32 & 878.46 \\
\hline 2001 & $6,895.20$ & 764.96 & 662.53 & $1,269.32$ \\
\hline 2002 & $7,795.76$ & 930.49 & 764.90 & $1,505.96$ \\
\hline 2003 & $9,913.52$ & $1,096.54$ & $1,359.3$ & $1,952.92$ \\
\hline 2004 & $11,411.07$ & $1,421.66$ & $2,112.5$ & $2,131.82$ \\
\hline 2005 & $14,610.88$ & $1,838.39$ & $2,900.1$ & $2,637.91$ \\
\hline 2006 & $18,564.59$ & $2,290.62$ & $5,120.9$ & $3,797.91$ \\
\hline 2007 & $20,657.32$ & $3,668.66$ & $13,181.7$ & $5,127.40$ \\
\hline 2008 & $24,296.33$ & $6,920.50$ & $9,563.0$ & $8,008.20$ \\
\hline 2009 & $24,794.24$ & $9,110.86$ & $7,030.8$ & $9,419.92$ \\
\hline 2010 & $54,204.80$ & $10,157.02$ & $9,918.2$ & $11,034.94$ \\
\hline 2011 & $63,258.58$ & $10,660.07$ & $10,275.3$ & $12,172.49$ \\
\hline 2012 & $71,186.53$ & $14,649.28$ & $14,800.9$ & $13,895.39$ \\
\hline 2013 & $80,222.13$ & $15,778.31$ & $19,077.4$ & $15,158.62$ \\
\hline
\end{tabular}

SOURCES: (i) Central Bank of Nigeria Statistical Bulletin (various issues)

(ii) National Bureau of Statistics (various issues). 
The IISTE is a pioneer in the Open-Access hosting service and academic event management. The aim of the firm is Accelerating Global Knowledge Sharing.

More information about the firm can be found on the homepage:

http://www.iiste.org

\section{CALL FOR JOURNAL PAPERS}

There are more than 30 peer-reviewed academic journals hosted under the hosting platform.

Prospective authors of journals can find the submission instruction on the following page: http://www.iiste.org/journals/ All the journals articles are available online to the readers all over the world without financial, legal, or technical barriers other than those inseparable from gaining access to the internet itself. Paper version of the journals is also available upon request of readers and authors.

\section{MORE RESOURCES}

Book publication information: http://www.iiste.org/book/

Academic conference: http://www.iiste.org/conference/upcoming-conferences-call-for-paper/

\section{IISTE Knowledge Sharing Partners}

EBSCO, Index Copernicus, Ulrich's Periodicals Directory, JournalTOCS, PKP Open Archives Harvester, Bielefeld Academic Search Engine, Elektronische Zeitschriftenbibliothek EZB, Open J-Gate, OCLC WorldCat, Universe Digtial Library, NewJour, Google Scholar

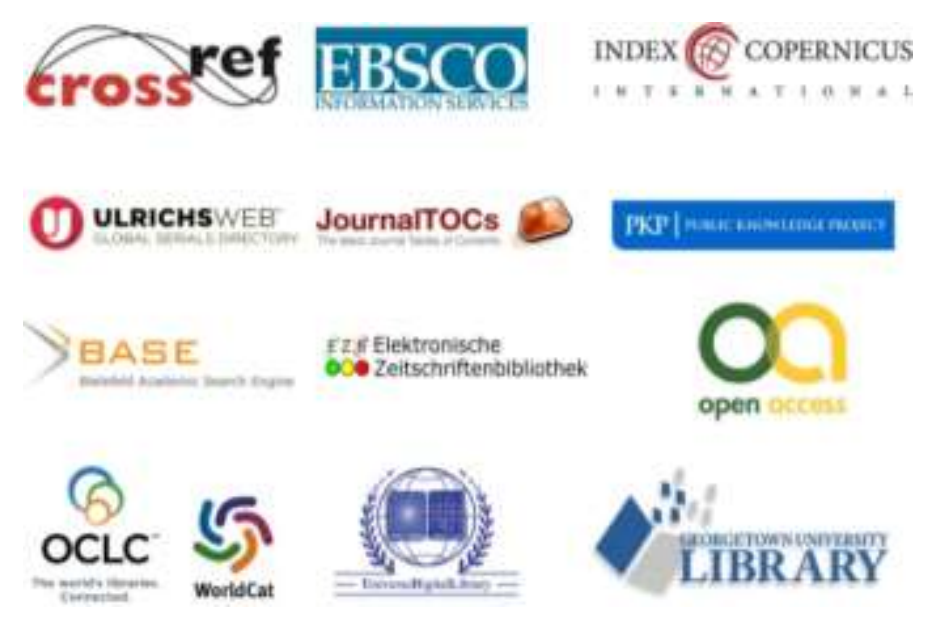

